\title{
DISTRIBUTION OF HOOLOCK GIBBON (BUNOPITHECUS HOоLоск HооLоск) IN INDIA AND BANGLADESH
}

\author{
J. Das ${ }^{1,2}$, M.M. Feeroz ${ }^{3}$, M.A. Islam ${ }^{4}$, J. Biswas ${ }^{1,2}$, P. Bujarborua ${ }^{5}$, D. Chetry ${ }^{1,2}$, \\ R. Medhi ${ }^{1,2}$ and J. Bose ${ }^{1}$ \\ ${ }^{1}$ Animal Ecology and Wildlife Biology Lab., Department of Zoology, Gauhati University, Guwahati, Assam 781014, India. \\ ${ }^{2}$ Primate Research Centre, Northeast Centre, Post Box. No. 152, Guwahati, Assam 781001, India. \\ ${ }^{3}$ Department of Zoology, Jahangirnagar University, Savar, Dhaka, Bangladesh. \\ ${ }^{4}$ Department of Zoology, University of Dhaka, Bangladesh. \\ ${ }^{5}$ Department of Botany, Gauhati University, Guwahati, Assam 781014, India. \\ Emails: ${ }^{1}$ gibbonconservation@yahoo.com; ${ }^{3}$ feeroz@juniv.edu $;{ }^{4}$ mahrukh@dhaka.net
}

\begin{abstract}
Western Hoolock Gibbon (Bunopithecus hoolock hoolock) is found in Bangladesh, India and Myanmar. In India and Bangladesh a total of 94 areas were recorded as Hoolock Gibbon habitat, of which 14 are in the northeastern and south-eastern region of Bangladesh and 80 are in northeastern India. All these areas are severely fragmented because of encroachment, illegal logging and development.
\end{abstract}

Keywords

Bunopithecus hoolock hoolock, Hoolock Gibbon, distribution, India, Bangladesh, threats, numbers

\section{Introduction}

Geographic distribution of all 12 species of gibbons are confined to the South East Asian countries and mostly within the tropics. Hoolock Gibbon is a monotypic species and its distribution range extends well outside the tropics. The western subspecies Bunopithecus hoolock hoolock is found in the northeastern and southeastern region of Bangladesh, seven states of northeastern India and western Myanmar. Debang-Brahmaputra river system in the west (Tilson, 1979) and Cindwin River in the east act as barriers for the distribution of this sub-species (Groves, 1967; 1972).

Anderson, in the year 1878, first reported the presence of Hoolock Gibbon in the Chittagong Hill Tracts of Bangladesh. Prater (1971), Green (1978), Khan (1981), Gittins (1980), Gittins and Akonda (1982), and Siddiqi (1986) have also recorded the presence of Hoolock Gibbon in different forests of Bangladesh. Besides specimen collection localities, several authors have recorded the distribution in different states of northeastern India. In Meghalaya (Alfred \& Sati, 1986, 1990; Choudhury, 1991), in Tripura (Mukherjee, 1984, 1986; Singh, 1989; Gupta, 1994), in Arunachal Pradesh (Tilson, 1979; Choudhury, 1991; Borang \&
Thapliyal, 1993; Mukherjee et al., 1988; 1991-92), in Nagaland (McCann, 1933), in Assam (Choudhury, 1987, 1988, 1990, 1991, 1996, 2000) and in Mizoram (Raman et al., 1995).

Although forest destruction is a global phenomenon, its rate within the distribution range of this species is very high due to rapid population growth. Being a completely forest canopy dependent, frugivorous, brachiator and territorial species, the effects of forest destruction and fragmentation on this species is severe. Moreover, monogamous nature, small group size, slow growth rate and long parental care have multiplied the effect. In the global context this species is endangered. Before drawing a proper conservation action plan for this taxa, detailed distributional record for the species is essential. Except for a few collection localities from Myanmar no survey records are available till date. This paper deals with the distribution of the western subspecies of Hoolock Gibbon in India and Bangladesh where surveys were carried out.

\section{Methods}

Detailed surveys have been carried out in India between 1995 and 2001 (under Indo-US Primate Project) and in Bangladesh 


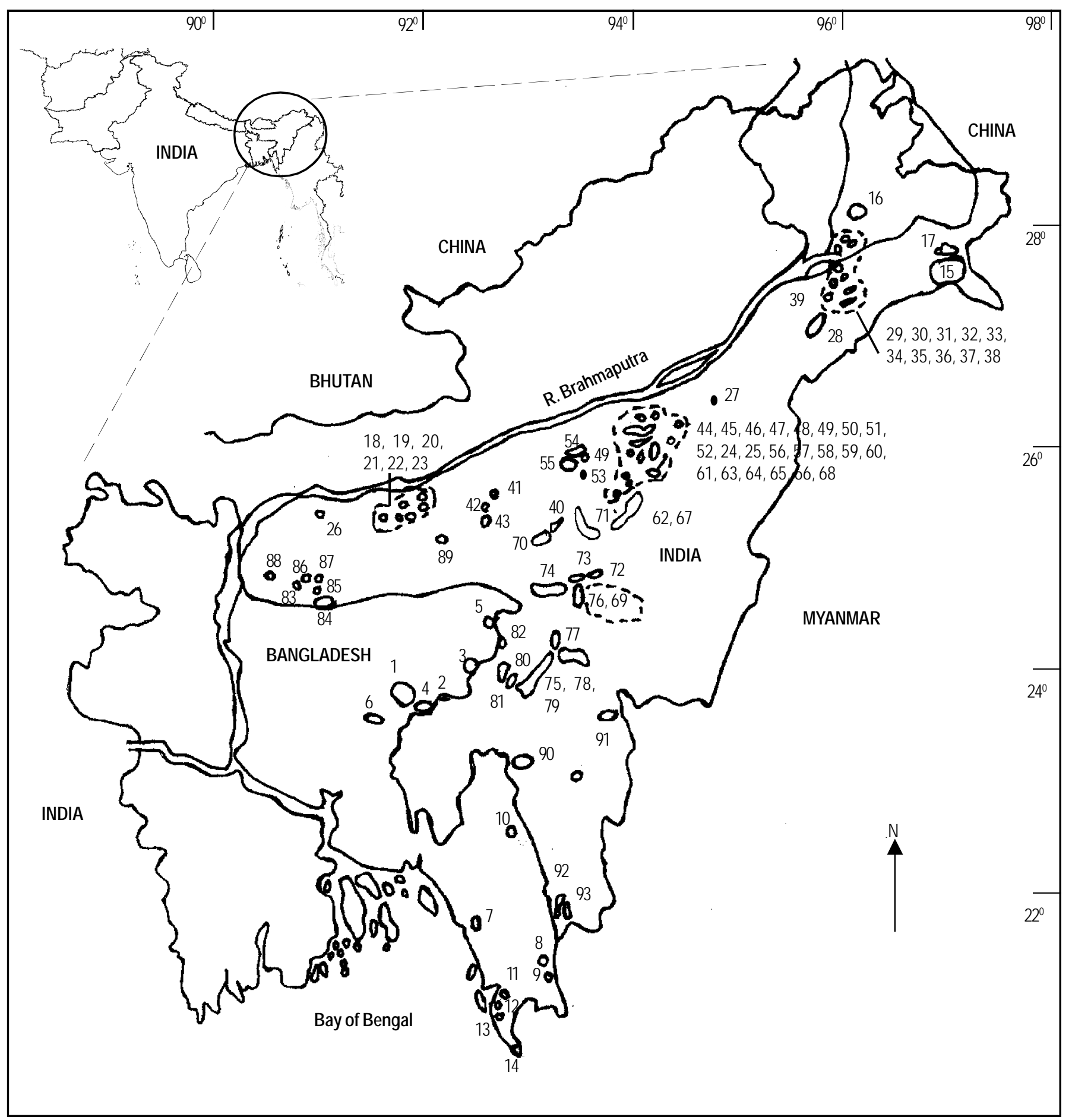

Figure 1. Map showing the distribution of Hoolock Gibbon in India and Bangladesh. See localities on facing page. 
Locations of Hoolock Gibbon distribution in India and Bangladesh as per the map on opposite page.

Bangladesh

1. West Bhanugach FR

2. Adampur

3. Rajkandhi

4. Horin chara

5. Patharia

6. Shatchari

7. Chunati

8. Satghar

9. Padua

10. Hazarikhil

11. Bhomarighona

12. Ukhia

13. Himchari

14. Teknaf

\section{India}

15. Namdapha NP

16. Miao RF

17. Kamlang WLS

18. Kuwasingh RF

19. Jorsal RF

20. Rani RF

21. Gorbanga RF

22. Lulshi plantation reserve

23.Pantan RF

24. Nambar RF

25. Panbari RF

26. Moghaghar RF

27. Gibbon WLS

28. Joypur RF

29. Upper Dehing West Block RF

30. Upper Dehing East Block RF

31. Buri Dehing RF

32. Hahkati RF

33. Kakojan RF

34. Kumsang RF

35. Mesaki RF

36. Kundilkalia RF

37. Dibang Valley RF

38. Podumoni-Bherjan-Borajan WLS

39. Dibru-Saikhowa NP

40. Amreng RF

41. Amsolong PRF

42. Balasore PRF

43. Umjakini PRF

44. Mikir Hills RF

45. Kalioni RF

46. Khonbamon RF

47. Nambor North Block RF

48. Nambor West Block RF

49. Jungphung RF

50. Patradisha RF

51. Longnith RF

52. Haithapahar DCRF

53. Mahamaya DCRF
54. Borjuri PRF

55. Western Mikir Hills PRF

56. Lanlakso PRF

57. Kaziranga PRF

58. Dalamora PRF

59. Kalapahar RF

60. Bokajan PRF

61. Tikok PRF

62. Danshiri RF

63. Daldii RF

64. Disama RF

65. Englongari DCRF

66. Miyungdisa DCRF

67. Borlanfer DCRF

68. Hafjan PRF

69. Barail RF

70. Khrumming RF

71. Langting Mupa RF

72. Panimur PRF

73. Barail PRF

74. North Cachar Hills RF

75. Innerlinr RF

76. Barail Rf

77. Katakhal RF

78. Innerline RF

79. Innerline RF

80. Longai RF

81. Singla RF

82. Patharia RF

83. Nokrek NP

84. Balpakram NP

85. Siju WLS

86. Rewak RF

87. Baghmara RF

88. Songsek-Tasek RF

89. Nongkhylem WLS

90. Dampa WLS

91. Murlen NP

92. Nengpui WLS

93. Nengpui RF between 1990 and 2001. This species occurs in all the seven states of northeastern India, viz., Arunachal Pradesh, Assam, Megalaya, Mizoram, Nagaland, Manipur and Tripura. Most of this survey was confined to Assam and parts of Meghalaya, Mizoram and Arunachal Pradesh. Most of the areas within the gibbon distribution range have been surveyed in Bangladesh except in parts of Chittagong Hill Tracts.

Locations of Western Hoolock Gibbon were recorded from transects. On an average $15 \mathrm{~km}$ of pre-determined transects (modified pre-existing forest trails) were surveyed for locating groups while covering at least $10-15 \%$ of the total forest area. Transects were laid in a stratified random manner to cover all the representative areas of the forest (Muller-Dombois \& Ellenberg, 1974; Kent \& Coker, 1994). Surveys were carried out on foot, from $0600-1800 \mathrm{hr}$ with a break of one hour at mid-day. Each day a distance of $10-18 \mathrm{~km}$ was covered by walk at a speed of $1.5 \mathrm{~km}$ $\mathrm{hr}^{-1}$ or less, depending on the weather condition and habitat type, with occasional stops of one minute to look around for animals. Songs were also recorded during the transect walk. Group size and composition were recorded when groups were located. The habitat or forest type of each area was recorded as evergreen, semi-evergreen, broad leaf mixed evergreen, deciduous, etc.

Extent of occurrence and area of occupancy were calculated as defined by the IUCN Red List Criteria and Categories (IUCN, 2001).

The biomass of this species was calculated by using the average body weight of adult males and females and multiplying it by the respective individual density. Metabolic biomass was calculated by considering 0.75 of body weight, as in Eisenberg et al. (1979), Freese et al. (1982), Kohlhaas (1988), Janson and Emmons (1990), Pontes (1999) and Feeroz (1999). This allows for $50 \%$ of the group being immature, thus markedly lowering group weight. Adult body weights for males and females of this species are taken from existing literature (Chivers, 1977).

\section{Results and Discussion}

Data presented here are from $8,000 \mathrm{~km}^{2}$ of the surveyed areas in India (Das, 2002) and $900 \mathrm{~km}^{2}$ areas from Bangladesh. Surveyed areas were calculated by multiplying the length of the transect walk and twice the average visibility in transects. Total area of occupancy, number of groups, mean group size, biomass and metabolic biomass of Hoolock Gibbons found in these countries are given in Table 1.

\section{Distribution and threats to Hoolock Gibbons in Bangladesh}

Hoolock Gibbons are only found in the northeastern and southeastern evergreen and semi-evergreen forests of Bangladesh. Six areas in the northeast and eight areas in the southeast were recorded as gibbon habitats (Fig. 1). All the 14 
areas are distinctly separate from each other. The area of occupancy of this species in Bangladesh has been calculated to be less than $200 \mathrm{~km}^{2}$. As many as 25 areas were recognized by earlier workers as Hoolock Gibbon habitats, of which only 14 areas have been confirmed by several recent surveys (Table 2). No survey has been done in other areas. A total of 118 gibbons were recorded, with the number of gibbons in each area varying from 3 to 33 .

The major threat to the survival of the Hoolock Gibbons in Bangladesh is habitat destruction, which causes rapid reduction of food trees, sleeping trees and trees used for travel. Habitat destruction is primarily due to fuel wood extraction, timber extraction, edible piper leaf plantation, plantation of exotic plant species, crop cultivation, modification of undergrowth, land erosion, road expansion and construction. Unplanned intensive tourism, hunting, army training, food species shared by human and establishment of gas field are the other threats.

\section{Distribution and threats to Hoolock Gibbons in India}

Although the 'extent of occurrence' of this species has been calculated to $>1,50,000 \mathrm{~km}^{2}$ the 'area of occupancy' is relatively very small. Moreover, the habitats are fragmented and are far apart from one another. In northeastern India, 80 areas were recorded as gibbon habitat (Table 2), (Map 1). A total of 379 gibbons were recorded, and the number varied from 1 to 25 among these areas.

As northeastern India is an assemblage of multicultural communities and land use pattern are different in different areas, threats to this species are distinct particularly in areas dominated by tribals. Area specific threats are shown in the table 2. Habitat destruction, encroachment and hunting are the major threats to this species in India. The major types of habitat destruction are 'jhum cultivation' both 'pan jhum' (edible Piper leaf cultivation by lopping most of the branches of all trees in cultivation area) and 'mixed jhum', expansion of agricultural lands, expansion of tea gardens and construction of roads through Reserve Forests, District Council Reserved Forests and proposed Reserve Forests. Several tribes in this region hunt Hoolock Gibbon for meat, bones, blood, etc.

\section{Acknowledgement}

We are thankful to the Forest Department Officials and the staffs of the respective countries who have directly or indirectly helped us for providing permissions and field support. India: We are grateful to Prof. S.M. Mohnot and Prof. P.C. Bhattacherjee for providing all financial and logistic support under the Indo-US Primate Project (Grant No- INT/FWS-22). This work was facilitated by the extensive cooperation from the Forest Department officials particularly Mr. S.N. Kalita, Mr. D.N. Singh, Mr. S. Doley, Late Mr. N.C. Sharma, Mr. S. Sargeyary, Mr. A. Rava, Mr. P. Jidung, Mr. T.T.C. Marak and Mr. S. Srivastava. Dr.
A. Srivastava, Ms. F. Begum, Mr. U. Phukan, Mr. G. Ahmed, Mr. R. Nath, Mr, G. Banik and Mr. L.S. Darney helped us in the field to carry out the survey. Bangladesh: Field studies were supported by several funding organizations viz., Multi Disciplinary Action Research Centre (MARC-Bangladesh); Commonwealth University Commission, UK; Lundgren Fund; the Newton Trust Fund; Fund from the Department of Anatomy, University of Cambridge and Cott Fund (Selwyn College). We are also indebted to Dr. D.J. Chivers of the University of Cambridge, Prof. C. Southwick of University of Colorado for their constant support throughout the study period. They visited the field several times and made suggestions to enrich the fieldwork.

\section{References}

Alfred, J.R.B. and J.P. Sati (1986). The gibbon with special reference to Hylobates hoolock, pp 384-390. In: Majupuria T.C. (editor). Wildlife Wealth of India: Resource and Management. Tec Press Service, Bangkok.

Alfred, J.R.B. and J.P. Sati (1990). Survey and census of the Hoolock Gibbon in West Garo Hills, Northeast India. Primates 31(2): 299-306. Anderson, J. (1878). Anatomical and Zoological Researches. Comprising an account of the zoological results of the two expeditions to western Yunnan in 1868 and 1875. Quaritch, London.

Borang, A. and G.S. Thapliyal (1993). Natural distribution and ecological status of non-human primates in Arunachal Pradesh. Indian Forester 119(10): 834-844.

Choudhury, A. (1987). Notes on the distribution and conservation of Phayre's Leaf Monkey and Hoolock Gibbon in India. Tigerpaper 14(2): 2-6.

Choudhury, A. (1988). A primary survey in southern Assam, India. Primate Conservation 9: 123-125.

Choudhury, A. (1990). Population dynamics of Hoolock Gibbon (Hylobates hoolock) in Assam, India. American Journal of Primatology 20: 37-41.

Choudhury, A. (1991). Primate survey in southern Assam, India. Primate Conservation 9: 123-125.

Choudhury, A. (1996). A survey of Hoolock Gibbon (Hylobates hoolock) in southern Assam, India. Primate Report 44: 77-85.

Choudhury, A. (2000). A survey of Hoolock Gibbon (Hylobates hoolock) in Dibru-Saikhowa National Park, Assam, India. Primate Report 56: 61-66.

Das, J. (2002). Socioecology of Hoolock Gibbon: (Hylobates hoolock hoolock) in response to habitat change. Ph.D. Thesis, Guwahati University, 266pp (unpublished).

Eisenberg, J.F., M.A. O'connel, and P. August (1979). Density and distribution of mammals in two Venezuelan habitats, pp. 187-207. In: Eisenberg, J.F. (editor). Vertebrate Ecology in the Northern Neotropics. Smithsonian Institution Press, Washington DC.

Feeroz, M.M. (1999). The ecology and behaviour of the Pig-tailed Macaque (Macaca nemestrina leonina) in Bangladesh. Ph.D. Thesis. University of Cambridge, Cambridge (unpublished).

Freese, C.H., P.G. Heltne, C.R. Napoleon and G. Whitesides (1982). Patterns and determinants of monkeys densities in Peru and Bolivia, with notes on distribution. International Journal of Primatology 3: 53-90.

Gittins, S.P. (1980). A survey of primates of Bangladesh. Report to FAO. 
Gittins, S.P. and A.W. Akonda (1982). What survives in Bangladesh? Oryx 16(3): 5-11.

Green, K.M. (1978). Primates of Bangladesh: A preliminary survey of population and habitat. Biological Conservation 13: 141-160.

Groves, C.P. (1967). Geographic variation in the Hoolock or Whitebrowed Gibbon (Hylobates hoolock Harlan, 1834). Folia Primatologica 7: 276-283.

Groves, C.P. (1972). Systematics and phylogeny of gibbons, pp. 189. In: Rumbaugh, D.M. (editor) Gibbon and Siamang. Karger, Basel. Gupta, A.K. (1994). Status and conservation of non human Primates in Tripura, India, pp. 101-111. In: Thierry, B., J.R. Anderson, J.J. Roeder and N. Herrenschmidt (editors).Current Primatology: Ecology and
Table 1. Area of occupancy, number of groups, mean group size, biomass and metabolic biomass of Hoolock Gibbons found in India and Bangladesh.

\begin{tabular}{llllll}
\hline Country & $\begin{array}{l}\text { Area of } \\
\text { occupancy } \\
\text { sq km }\end{array}$ & $\begin{array}{l}\text { No. of } \\
\text { groups } \\
\text { (range) }\end{array}$ & $\begin{array}{l}\text { Mean group } \\
\text { Size }\end{array}$ & Biomass & $\begin{array}{l}\text { Metabolic } \\
\text { biomass }\end{array}$ \\
\hline Bangladesh & 134 & 36 & $\begin{array}{l}3.03 \pm 0.82 \\
(2-5)\end{array}$ & 826 & 619.5 \\
India & 470 & 129 & $\begin{array}{l}3.32 \pm 0.35 \\
(2-4)\end{array}$ & 2653 & 1989 \\
& & & & & \\
\hline
\end{tabular}

Table 2. Distribution and status of Hoolock Gibbon in South Asia.

\begin{tabular}{|c|c|c|c|c|}
\hline $\begin{array}{l}\text { Countryl } \\
\text { Area }\end{array}$ & Locality & Habitat & Threats & $\begin{array}{l}\text { Total no. of } \\
\text { individuals }\end{array}$ \\
\hline
\end{tabular}

BANGLADESH

Sylhet

Moulvibazar

$\begin{array}{ll} & \begin{array}{l}\text { Adampur } \\ \text { Rajkandhi } \\ \text { Horin chara }\end{array} \\ & \text { Pathalia } \\ \text { Hobigong } & \text { Shatchari } \\ \text { Chittagong } & \\ \text { Chittagong } & \text { Chunati } \\ & \text { Satghar } \\ & \text { Padua } \\ & \text { Hazarikhil } \\ \text { Cox's Bazar } & \text { Bhomarighona } \\ \text { Cox's Bazar } & \text { Ukhia } \\ & \text { Himchari } \\ & \text { Teknaf }\end{array}$

INDIA

Arunachal Pradesh

$\begin{array}{lll}\text { Changlang } & \begin{array}{l}\text { Namdapha NP } \\ \text { Miao RF }\end{array} & \begin{array}{l}\text { Evergreen } \\ \text { semi evergreen }\end{array} \\ \text { Lohit } & \text { Kamlang WLS } & \text { Evergreen } \\ \text { Assam } & \text { Kuwasingh RF } & \text { Tropical moist deciduous } \\ \text { Kamrup } & \text { Jorsal RF } & \text { Tropical moist deciduous } \\ \end{array}$

Semi-evergreen, tropical moist deciduous

Semi-evergreen, tropical moist deciduous

Semi-evergreen, broad leaf mixed evergreen

Evergreen
Habitat destruction, tourism, encroachment, gas field exploration

Timber plantation, habitat destruction, encroachment 7

Timber plantation, habitat destruction, encroachment 5

Habitat destruction, encroachment 6

Habitat destruction, encroachment

19

Habitat destruction, encroachment

6

Habitat destruction, encroachment

3

Habitat destruction, encroachment, hunting

3

Habitat destruction, selective logging, encroachment 7

Habitat destruction, encroachment 6

Habitat destruction, encroachment 3

Habitat destruction, encroachment, fragmentation 4

Habitat destruction, hunting $\quad 17$

Habitat destruction, encroachment, hunting 2

Habitat destruction, encroachment, hunting 1

Habitat destruction, encroachment 10

Habitat destruction, encroachment 3 


\begin{tabular}{|c|c|c|c|c|}
\hline $\begin{array}{l}\text { Countryl } \\
\text { Area }\end{array}$ & Locality & Habitat & Threats & $\begin{array}{l}\text { Total no. of } \\
\text { individuals }\end{array}$ \\
\hline & Rani RF & Tropical moist deciduous & Habitat destruction, encroachment & 12 \\
\hline & Gorbanga RF & Tropical moist deciduous & Habitat destruction, encroachment & 2 \\
\hline & Kulsi Plantation RF & Tropical moist deciduous & Habitat destruction, encroachment & 5 \\
\hline & Pantan RF & Tropical moist deciduous & Habitat destruction, encroachment & 2 \\
\hline \multirow[t]{2}{*}{ Golaghat } & Nambar RF & Tropical semi evergreen & Habitat destruction, encroachment, hunting & 3 \\
\hline & Panbari RF & Tropical semi evergreen & Habitat destruction, encroachment, hunting & 3 \\
\hline Goalpara & Moghaghar RF & Tropical moist deciduous & Habitat destruction, encroachment, hunting & 1 \\
\hline Jorhat & Gibbon WLS & Tropical wet evergreen & Habitat destruction, encroachment & 20 \\
\hline Dibrugarh & Joypur RF & Tropical wet evergreen & Habitat destruction, encroachment, hunting & 12 \\
\hline \multirow[t]{11}{*}{ Tinsukia } & Upper Dehing West block RF & Tropical wet evergreen & Habitat destruction, encroachment & 1 \\
\hline & Upper Dehing East block RF & Tropical wet evergreen & Habitat destruction, encroachment & 2 \\
\hline & Buri Dehing RF & Tropical wet evergreen & Habitat destruction, encroachment, hunting & 1 \\
\hline & Hahkati RF & Tropical wet evergreen & Habitat destruction, encroachment & 3 \\
\hline & Kakojan RF & Tropical wet evergreen & Habitat destruction, encroachment & 2 \\
\hline & Kumsang RF & Tropical wet evergreen & Habitat destruction, encroachment & 1 \\
\hline & Mesaki RF & Tropical wet evergreen & Habitat destruction, encroachment & 4 \\
\hline & Kundilkalia RF & Tropical wet evergreen & Habitat destruction, encroachment & 2 \\
\hline & Dibang Valley RF & Tropical wet evergreen & Habitat destruction, encroachment & 3 \\
\hline & Podumoni-Bherjan-Borajan WLS & Tropical wet evergreen & Habitat destruction, encroachment & 11 \\
\hline & Dibru-Saikhowa NP & Tropical wet evergreen & Habitat destruction, encroachment & 4 \\
\hline \multirow[t]{19}{*}{ Karbi-Anglong } & Amreng RF & Tropical semi evergreen & Habitat destruction, hunting, encroachment & 1 \\
\hline & Amsolong PRF & Tropical semi evergreen & Habitat destruction, hunting, encroachment & 1 \\
\hline & Balasore PRF & Tropical semi evergreen & Habitat destruction, hunting, encroachment & 2 \\
\hline & Umjakini PRF & Tropical semi evergreen & Habitat destruction, hunting, encroachment & 1 \\
\hline & Mikir Hills RF & Tropical semi evergreen & Habitat destruction, hunting, encroachment & 5 \\
\hline & Kalioni RF & Tropical semi evergreen & Habitat destruction, hunting, encroachment & 3 \\
\hline & Khonbamon RF & Tropical semi evergreen & Habitat destruction, hunting, encroachment & 1 \\
\hline & Nambor North Block RF & Tropical semi evergreen & Habitat destruction, hunting, encroachment & 4 \\
\hline & Nambor West Block RF & Tropical semi evergreen & Habitat destruction, hunting, encroachment & 2 \\
\hline & Jungthung RF & Tropical semi evergreen & Habitat destruction, hunting, encroachment & 6 \\
\hline & Patradisa RF & Tropical semi evergreen & Habitat destruction, hunting, encroachment & 3 \\
\hline & LongnitRF & Tropical semi evergreen & Habitat destruction, hunting, encroachment & 7 \\
\hline & Haithapahar DCRF & Tropical semi evergreen & Habitat destruction, hunting, encroachment & 1 \\
\hline & Mahamaya DCRF & Tropical semi evergreen & Habitat destruction, hunting, encroachment & 1 \\
\hline & Borjuri PRF & Tropical semi evergreen & Habitat destruction, hunting, encroachment & 3 \\
\hline & Western Mikir Hills PRF & Tropical semi evergreen & Habitat destruction, hunting, encroachment & 8 \\
\hline & Lanlakso PRF & Tropical semi evergreen & Habitat destruction, hunting, encroachment & \\
\hline & Kaziranga PRF & Tropical semi evergreen & Habitat destruction, hunting, encroachment & 2 \\
\hline & Dalamora PRF & Tropical semi evergreen & Habitat destruction, hunting, encroachment & 1 \\
\hline
\end{tabular}




\begin{tabular}{|c|c|c|c|c|}
\hline $\begin{array}{l}\text { Countryl } \\
\text { Area }\end{array}$ & Locality & Habitat & Threats & $\begin{array}{l}\text { Total no. of } \\
\text { individuals }\end{array}$ \\
\hline & Kalapahar PRF & Tropical semi evergreen & Habitat destruction, hunting, encroachment & 3 \\
\hline & Bokajan PRF & Tropical semi evergreen & Habitat destruction, hunting, encroachment & 1 \\
\hline & Tikok PRF & Tropical semi evergreen & Habitat destruction, hunting, encroachment & 1 \\
\hline & Danshiri RF & Tropical semi evergreen & Habitat destruction, hunting, encroachment & 10 \\
\hline & Daldali RF & Tropical semi evergreen & Habitat destruction, hunting, encroachment & 1 \\
\hline & Disama RF & Tropical semi evergreen & Habitat destruction, hunting, encroachment & 1 \\
\hline & Englongari DCRF & Tropical semi evergreen & Habitat destruction, hunting, encroachment & 2 \\
\hline & Miyungdisa DCRF & Tropical semi evergreen & Habitat destruction, hunting, encroachment & 3 \\
\hline & Borlanfer DCRF & Tropical semi evergreen & Habitat destruction, hunting, encroachment & 5 \\
\hline & Hafjan PRF & Tropical semi evergreen & Habitat destruction, hunting, encroachment & 1 \\
\hline \multirow[t]{6}{*}{ North Cachar Hills } & Barail RF & Tropical wet evergreen & Habitat destruction, hunting, encroachment & 3 \\
\hline & Khrumming RF & Tropical wet evergreen & Habitat destruction, hunting, encroachment & 10 \\
\hline & Langting Mupa RF & Tropical semi evergreen & Habitat destruction, hunting, encroachment & 15 \\
\hline & Panimur PRF & Sub tropical broad leaved hill & Habitat destruction, hunting, encroachment & 1 \\
\hline & Barail PRF & Tropical wet evergreen & Habitat destruction, hunting, encroachment & 3 \\
\hline & North Cachar Hills RF & Tropical wet evergreen & Habitat destruction, hunting, encroachment & 6 \\
\hline \multirow[t]{2}{*}{ Cachar } & Innerlinr RF & Tropical wet evergreen & Habitat destruction, hunting, encroachment & 22 \\
\hline & Barail RF & Tropical wet evergreen & Habitat destruction, hunting, encroachment & 5 \\
\hline \multirow[t]{2}{*}{ Hailakandi } & Katakhal RF & Tropical wet evergreen & Habitat destruction, hunting, encroachment & 3 \\
\hline & Innerline RF & Tropical wet evergreen & Habitat destruction, hunting, encroachment & 1 \\
\hline \multirow[t]{4}{*}{ Karimganj } & Innerline RF & Tropical wet evergreen & Habitat destruction, hunting, encroachment & 4 \\
\hline & Longai RF & Tropical semi evergreen & Habitat destruction, hunting, encroachment & 3 \\
\hline & Singla RF & Tropical semi evergreen & Habitat destruction, hunting, encroachment & 5 \\
\hline & Patharia RF & Tropical semi evergreen & Habitat destruction, hunting, encroachment & 3 \\
\hline \multicolumn{5}{|l|}{ Meghalaya } \\
\hline East Garo Hills & Nokrek NP & Tropical moist decidious & Habitat destruction, horticulture, hunting & 25 \\
\hline \multirow[t]{4}{*}{ South Garo Hills } & Balpakram NP & Tropical moist decidious & Habitat destruction, encroachment, hunting & 16 \\
\hline & Siju WLS & Tropical moist decidious & Habitat destruction, horticulture, hunting & 3 \\
\hline & Rewak RF & Tropical moist decidious & Habitat destruction, horticulture, hunting & 2 \\
\hline & Baghmara RF & Tropical moist decidious & Habitat destruction, hunting & 2 \\
\hline East Garo Hills & Songsek-Tasek RF & Tropical moist decidious & Habitat destruction, horticulture, hunting & 20 \\
\hline Ribhoi & Nongkhylem WLS & Tropical moist decidious & Habitat destruction, hunting, encroachment & 3 \\
\hline \multicolumn{5}{|l|}{ Mizoram } \\
\hline Mamit & DampaWLS & Tropical wet evergreen & Habitat destruction, hunting, encroachment & 3 \\
\hline Champai & Murlen NP & Tropical wet evergreen & Habitat destruction, hunting & 8 \\
\hline \multirow[t]{2}{*}{ Cintuipui } & Nengpui WLS & Tropical wet evergreen & Habitat destruction, hunting & 3 \\
\hline & Nengpui RF & Tropical wet evergreen & Habitat destruction, hunting & 1 \\
\hline
\end{tabular}

NP- National Park; WLS - Wildlife Sanctuary; RF- Reserved Forest; DCRF- District Council Reserved Forest; PRF- Proposed Reserve Forest; USF- Unclassified State Forest 
Evolution. Strasbourg University, Louis Pasteur.

IUCN (2001). IUCN Red List Categories and Criteria: Version 3.1. IUCN Species Survival Commission. IUCN, Gland, Switzerland and Cambridge, UK, ii+30pp.

Janson, C.H. and L.H. Emmons (1990). Ecological structure of the non-flying mammal community at Cocha Cashu Biological Station, Manu National Park, Peru, pp. 314-338. In: Gentry, A.H. (editor). Four Neotropical Forests. Yale University Press, New Haven.

Kent, M. and P. Coker (1994). Vegetation Description and Analysis: A Practical Approach. John Wiley \& Sons, Chichester.

Khan, M.R.A. (1981). The non-human primates of Bangladesh. Tigerpaper 8(1): 12-15.

Kohlhaas, A.H. (1988). Primate populations in northern Bolivia. Primate Conservation 9: 93-97.

Mukherjee, R.P. (1984). The ecology of Hoolock Gibbon (Hylobates hoolock), of Tripura, India. International Journal of Primatology 5(4): 363.

Mukherjee, R.P. (1986). The ecology of Hoolock Gibbon (Hylobates hoolock) in Tripura, India. Primate Ecology and Conservation: 115124.

Mukherjee, R.P., S. Choudhury and A. Murmu (1988). Hoolock gibbons in Arunachal Pardesh, Northeast India: The Lohit District. Primate Conservation 9: 121-123.
Mukherjee, R.P., S. Choudhury and A. Murmu (1991-1992). Hoolock Gibbons (Hylobates hoolock) in Arunachal Pardesh, Northeast India: The Lohit District. Primate Conservation 12-13: 31-33.

Muller-Dombois, D. and H. Ellenberg (1974). Aims and Methods of Vegetation Ecology. John Wiley \& Sons, New York.

Pontes, M.A.R. (1999). Environmental determinants of primate abundance in Maraca island, roraima, Brazilian Amazonia. Journal of Zoological Society of London 247: 189-199.

Prater, S.H. (1971). The Book of Indian Animals. Bombay Natural History Society, Bombay.

Raman, S.T.R., C. Mishra and A.J.T. Johnsingh (1995). Survey of Primates of Mizoram, Northeast India. Primate Conservation 16: 5962.

Siddiqi, N.A. (1986). Gibbons (Hylobates hoolock) in the West Bhanugach Reserved Forest of Sylhet District, Bangladesh. Tigerpaper 13(3): 29-31.

Singh, R. (1989). Ontogeny of aggressive and submissive behavior in free living rhesus monkeys (Macaca mulatta). Proceedings of the Indian Academy of Science - Animal Science 98(2): 139-148.

Tilson, R.L. (1979). On the behavior of Hoolock Gibbons (Hylobates hoolock) during different seasons in Assam, India. Journal of the Bombay Natural History Society 4(1): 1-16.

\section{Many thanks to our external reviewers of 2002}

Dr. D.K. Agarwal, IARI, New Delhi

Dr. Mustak Ali, GKVK, Bangalore, Karnataka

Dr. Chellam Balasundaram, Bharathidasan University,

Thiruchirapalli, Tamil Nadu

Dr. D.B. Bastawade, ZSI, Pune, Maharashtra

Dr. B.K. Biswas, ZSI, Kolkata, West Bengal

Dr. M. Boppammal, Kongunadu Arts and Science College, Coimbatore, Tamil Nadu

Dr. A.K. Chakravarthy, R.R.S., Mandya, Karnataka

Dr. Anwaruddin Choudhury, The Rhino Foundation for Nature, Guwahati, Assam

Dr. Rema Devi, ZSI, Chennai, Tamil Nadu

Dr. Hemant V. Ghate, Modern College, Pune, Maharashtra

Dr. K.C. Gopi, ZSI, Kozhikode, Kerala

Dr. I.J. Gupta, ZSI, New Alipore, Kolkata, West Bengal

Dr. S.K. Gupta, Kolkata, West Bengal

Dr. Mohammad Hayat, Aligarh Muslim University, Aligarh, Uttar Pradesh

Dr. Sultan Ismail, Institute of Research in Soil Biology and Biotechnology, Chennai, Tamil Nadu

Dr. Salim Javed, Aligarh Muslim University, Aligarh, Uttar Pradesh

Dr. K.M. Kaveriappa, Mangalore University, Mangalore, Karnataka

Dr. M.S. Kodarkar, Vivek Vardhini College, Hyderabad, Andhra Pradesh

Dr. Sharat B. Krishna, University of Hemagangothri, Hassan, Karnataka

Dr. A.N. Madhyastha, Poornaprajna College, Udupi, Karnataka

Dr. S.C. Majumdar, ZSI, South 24 Parganas, West Bengal
Dr. G. Marimuthu, Madurai Kamaraj University, Madurai, Tamil Nadu

Dr. M. Mohanasundaram, TNAU, Mettupalayam, Tamil Nadu Dr. Muraleedharan, SACON, Coimbatore, Tamil Nadu Dr. Tilo Nadler, Endangered Primate Rescue Center, Vietnam

Dr. P.O. Nameer, KAU, Thrissur, Kerala

Dr. Goutaham Narayan, Pygmy Hog Conservation Programme, Guwahati, Assam

Dr. R. Natarajan, Emeritus Scientist, Chennai, Tamil Nadu Dr. H.R. Pajni, Punjab University, Chandigarh. Punjab Dr. H. Parulekar, National Institute of Oceanology, Dona Paula, Goa

Dr. Muhammed Jafer Palot, ZSI, Kozhikode, Kerala

Dr. C. Radhakrishnan, ZSI, Kozhikode, Kerala

Dr. D. Rajagopal, GKVK, Bangalore, Karnataka

Dr. H.S. Rose, Punjabi University, Patiala, Punjab

Dr. S. Sabesan, ICMR, Pondicherry

Dr. S. Sethuramalaingam, Regional Museum of Natural History, Mysore, Karnataka

Dr. H.S. Singh, GEER Foundation, Gandhinagar, Gujarat Dr. Mewa Singh, University of Mysore, Mysore, Karnataka Mr. Pritpal Soorae, IUCN/SSC Re-introduction Specialist Group, Dubai

Dr. C. Srinivasulu, Osmania University, Hyderabad, Andhra Pradesh

Dr. D.B. Tembre, Nagpur University, Maharashtra

Dr. G. Thirumalai, ZSI, Chennai, Tamil Nadu

Dr. B.K. Tyagi, ICMR, Madurai, Tamil Nadu

Dr. Vishva Vasu, Punjabi University, Patiala, Punjab

Dr. P. Venkatesan, Loyola College, Chennai, Tamil Nadu 